\title{
POŠTA
}

TELEKOMUNIKÁCIE A

ELEKTRONICKY OBCHOD

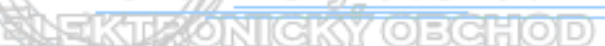

\section{REÁLNA IDENTIFIKÁCIA VYBRANÉHO KOMPONENTU V AUTOMOBILOVOM PRIEMYSLE PROSTREDNÍCTVOM RFID TECHNOLÓGIE}

\author{
Peter Kolarovszki ${ }^{1}$ Jiří Tengler $^{2}$ Juraj Vaculík $^{3}$ Ondrej Maslák $\mathbf{J a k u b}^{4}$ Unucka ${ }^{5}$
}

\section{Úvod}

Automobilový priemysel je kl'účovým priemyselným sektorom a ekonomickým pilierom viacerých krajín strednej a východnej Európy. Výrobcovia automobilov využívajú vzdelanú, produktívnu a pomerne lacnú pracovnú silu a kvalitné spojenie so západoeurópskymi trhmi ako aj výhodnú polohu pre export smerom na východ. Slovensko $\mathrm{v}$ súčasnosti patrí $\mathrm{k}$ dôležitým centrám svetového automobilového priemyslu, pričom vyrába najvyšší počet osobných automobilov na obyvatel'a na svete. Článok popisuje a stručne charakterizuje danú technológiu so zameraním sa na identifikáciu vybraného komponentu (predného svetlometu), ktorý je vyrábaný u subdodávatel'a pre automobilový priemysel. Technológia RFID je prudko sa rozvíjajúca technológia, hlavne čo sa týka jej aplikačných možností. V súčasnej dobe je možné sledovat' nárast aplikačných možností technológií automatickej identifikácie v rôznych oblastiach. Jednou z nich je automobilový priemysel, ktorý má na Slovensku značné zastúpenie. V rámci identifikácie svetlometu boli realizované rôzne typy merania čitatel'nosti. V záverečnej časti článku je obsiahnuté zhodnotenie výsledkov jednotlivých meraní.

\section{Technológia RFID}

Technológia rádio frekvenčnej identifikácie (RFID) nazývaná aj ako systém DSRC (Dedicated short range communication) je metóda automatickej identifikácie objektov prostredníctvom údajov uložených v RFID tagoch, ktoré sú rôzneho vyhotovenia, tvaru a vel'kostí. Údaje v tagoch slúžia na čítanie a môžu byt' editované podl'a potreby používatel'a. Čítanie a zapisovanie údajov zabezpečuje čítacie zariadenie (reader). Technológia využíva

\footnotetext{
${ }^{1}$ Ing. Peter Kolarovszki, PhD., Žilinská univerzita v Žiline, Fakulta prevádzky a ekonomiky dopravy a spojov, Katedra spojov, Univerzitná 8215/1, 01026 Žilina, Slovenská republika, tel.: +421 415133119 , fax: +421 41565 5615, e-mail: Peter.Kolarovszki@fpedas.uniza.sk

${ }^{2}$ Ing. Jiř́ Tengler PhD., Žilinská univerzita v Žiline, Fakulta prevádzky a ekonomiky dopravy a spojov, Katedra spojov, Univerzitná 8215/1, 01026 Žilina, Slovenská republika, tel.: +421 415133120 , fax: +421 41565 5615, e-mail: Tengler@fpedas.uniza.sk

${ }^{3}$ prof. Ing. Juraj Vaculík, PhD., Žilinská univerzita v Žiline, Fakulta prevádzky a ekonomiky dopravy a spojov, Katedra spojov, Univerzitná 8215/1, 01026 Žilina, Slovenská republika, tel.: +421 41513 3120, fax: +421 41565 5615, e-mail: juvac@fpedas.uniza.sk

${ }^{4}$ Ing. Ondrej Maslák, PhD., Žilinská univerzita v Žiline, Fakulta prevádzky a ekonomiky dopravy a spojov, Katedra spojov, Univerzitná 8215/1, 01026 Žilina, Slovenská republika, tel.: +421 41513 3120, fax: +421 41565 5615, e-mail:maslak@fpedas.uniza.sk

${ }^{5}$ Ing. Jakub Unucka, Gaben CZ s.r.o. jakub.unucka@gaben.cz
} 
elektromagnetické pole na prenos informácií. Systém zabezpečujúci spracovanie informácií z tagov v dosahu čítacieho zariadenie do informačného alebo riadiaceho systému sa nazýva middleware. $\mathrm{V}$ praxi sa so systémom môžeme stretnút' s rôznym vyhotovením.[2]

Všeobecne sa systém skladá z týchto častí:

- RFID identifikátor (tag) - sú malé elektronické zariadenia, ktoré sú pripevnené k objektom, resp. vložené do nich. Každý štítok má unikátny identifikátor a môže mat' aj iné prvky, ako napr. pamät' pre skladovanie údajov, senzory týkajúce sa životného prostredia ako aj bezpečnostné, kryptovacie a šifrovacie prvky.

Základná charakteristika RFID štítku zahŕňa:

- Vel'kost' a tvar antény

- Zdroj napájania.

- Snímací rozsah

- Prevádzkové frekvencie

- Funkcionalita.

- Orientácia (polarizácia)

RFID štítky sú rozdelené v závislosti od zdroja napájania pre komunikáciu a inej funkcionality do štyroch kategórií:

- Pasívne.

- Aktívne.

- Polo-pasívne.

- Polo-aktívne

- RFID čítacie zariadenia (reader) - sú zariadenia bezdrôtovo komunikujúce s RFID štítkami, za účelom identifikácie položiek spojených so štítkom a s možnost’ou pridružit' označovanej položke príslušné údaje. Štítok ako aj čítačka musia byt' za účelom dorozumievania prispôsobené rovnakým štandardom.

Vlastnosti RFID čítačiek, ktoré sú nezávislé na charakteristikách RFID štítku sú:

- výstupný výkon a pracovný cyklus RFID čítačky,

- prepojenie (rozhranie) s podnikovým podsystémom,

- mobilita,

- návrh a umiestnenie antény.

- Midlvér - Zabezpečuje riadenie ako aj filtráciu údajov a má 4 základné funkcie:

a. Zber údajov: Middleware je zodpovedný za extrakciu, združovanie, priebeh a filtrovanie údajov $\mathrm{z}$ mnohonásobných RFID snímačov z celej RFID siete.

b. Smerovanie údajov: RFID umožňuje spojenie RFID siete s podnikovými systémami. Robí tak smerovaním údajov do vhodných podnikových systémom v rámci podniku.

c. Riadenie procesov

d. Nástroj manažmentu: monitoruje a koordinuje snímače.

\section{Identifikácia vybraného komponentu v automotive}

Ako je možné vidiet' automobilový priemysel prudko rastie a s výrobou nových automobilov rastú nároky na identifikáciu dielcov, subdodávok ako aj na vysledovatel'nost' $\mathrm{v}$ rámci celého logistického ret’azca. Na Slovensku je množstvo subdodávatel'ov, ktorý vyrábajú rôzne komponenty a používajú pri preprave rôzne prepravné a manipulačné 
jednotky. V závislosti od štruktúry tovarov ako aj materiálu prepravných jednotiek je možné simulovat' implementáciu technológie RFID. Vyžaduje si to množstvo testov, či už čitatel'nosti RFID identifikátorov ako aj systémového prepojenia. V globálnom ponímaní je možné skonštatovat', že identifikácia prostredníctvom RFID môže byt' v rámci vnútropodnikovej logistiky subdodávatel'ského závodu alebo aj mimo podnikovej logistiky.

Testovanie sa zameriavalo na identifikáciu produktu - pravé a l'avé svetlomety pre Kia Sportage. Po kompletizácii svetlometu a kontrole kvality sú svetlá uložené do prepravného obalu, a tak vytvoria zároveň aj manipulačnú a prepravnú jednotku.

Svetlomety pre Kia Sportage sú balené a uložené na plastovej palete KIA Šedá (1200x800x145mm) - obr. 1, v šiestich plastových prepravkách, v troch vrstvách po dva kusy. Svetlá sú vložené do plastovej prepravky s priehradkou. Do každej prepravky sa vložia dva kusy svetlometov - obr. 2, spolu 12 ks svetlometov na paletu. Prepravná jednotka je bez ESD ochrany.

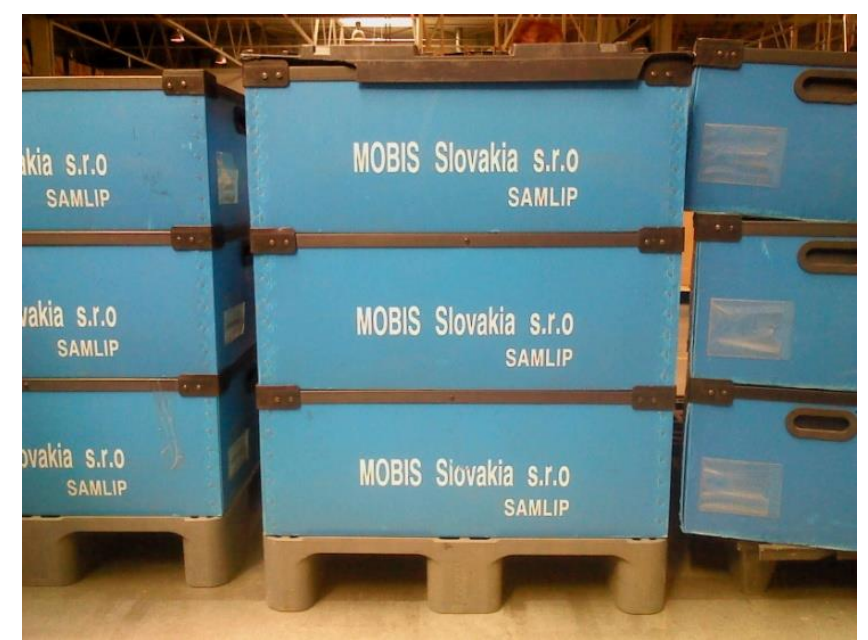

Obrázok 1: Prepravná jednotka - platová paleta (tri vrstvy prepraviek, po dva kusy vo vrstve, plastové veko)

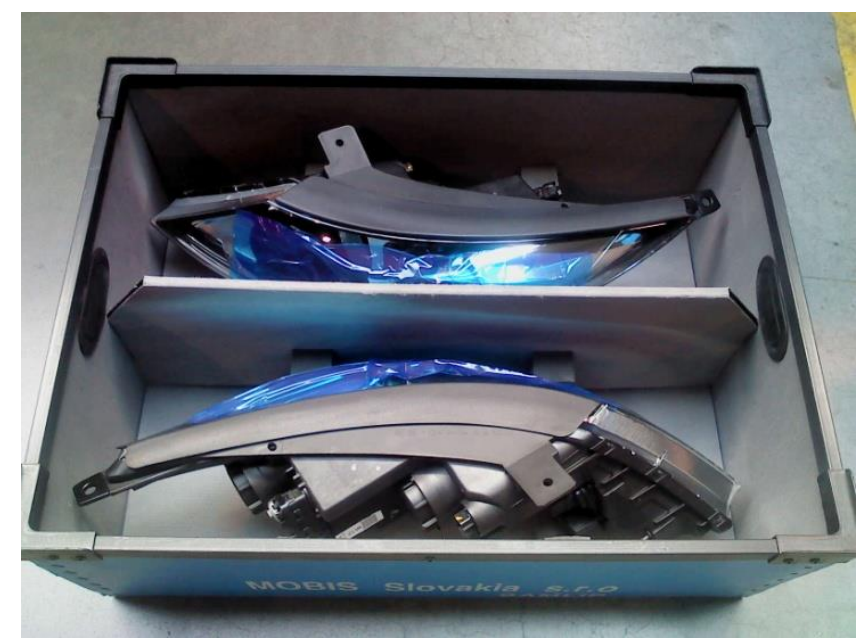

Obrázok 2: Uloženie svetlometov v prepravke

\section{Konfigurácia RFID komponentov pre potreby merania}

Pre potreby testovania boli použité pasívne UHF RFID identifikátory soperačnou frekvenciou 865-868 MHz (obr. 3, 5), s ktorou je reálne dosiahnut' čitatel'nost' do 6 metrov. 

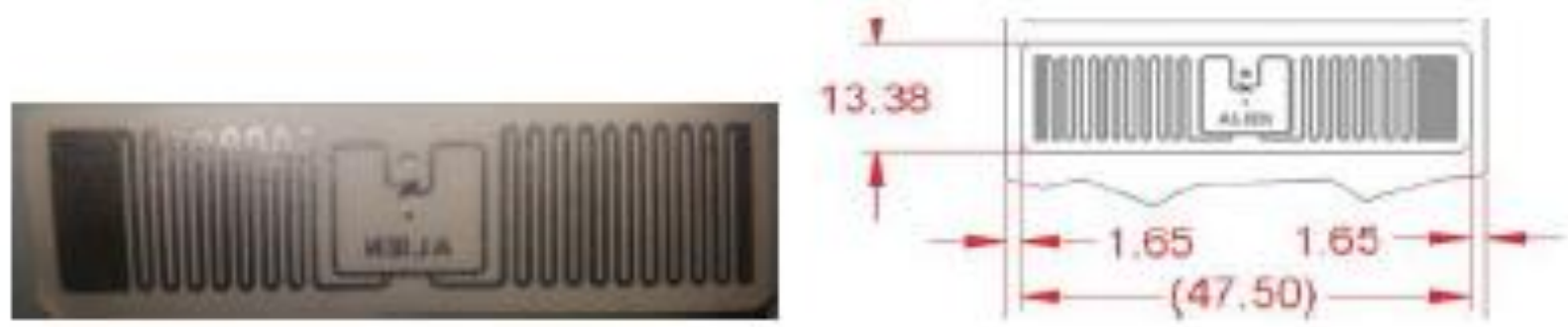

Obrázok 3. Použitý RFID tag

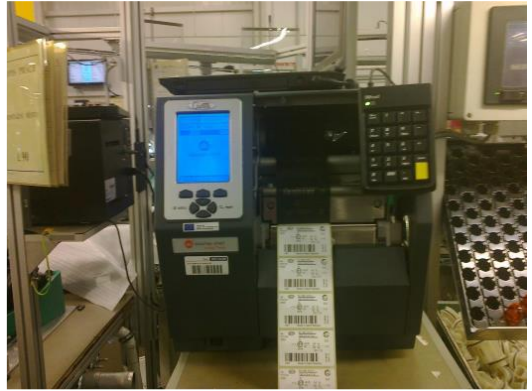

Obrázok 4. RFID tlačiareň

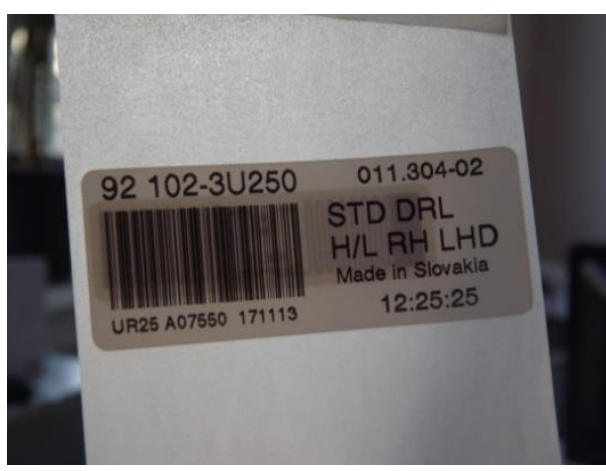

Obrázok 5. Vytlačený RFID štítok

RFID čítacie zariadenia sú neoddelitel'nou súčast'ou systémov RFID. Pomocou nich je možné všetky údaje v štítkoch prečítat' do použitel'nej a d'alej spracovatel'nej podoby. Č́tacie zariadenie obsahuje anténu, tá môže byt' interná, ktorá je priamo zabudovaná v snímači, alebo externá. Č́tačka, ku ktorej je možné pripojit' externú anténu, obsahuje 1 alebo viacej portov, ku ktorým sa antény pripájajú. Pre potreby merania bolo použité čítacie zariadenie Motorola FX7400 (obr.6).

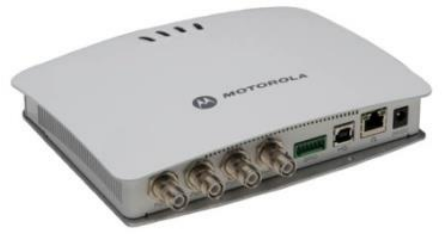

Obrázok 6. Motorola FX7400

Každý RFID systém generuje isté dáta, ktoré musia byt' nejakým spôsobom spracované. Typ týchto dát, ako aj spôsoby ich spracovania sa samozrejme líšia podl'a konkrétnej implementácie systému a podl'a účelu, na ktorý bol tento systém nasadený. Pre účely testovania bola vytvorená aplikácia v programe AMP (obr. 7), ktorý je súčasne midlevérom pre filtrovanie a správu údajov. Po načítaní jednotlivých RFID tagov, v rámci jednotlivých typov meraní sa nám údaje ukladali do databázy. Následnými dopytmi na databázu prostredníctvom jazyka SQL sa nám podarilo vyhodnotit' celkový priebeh testovania. 


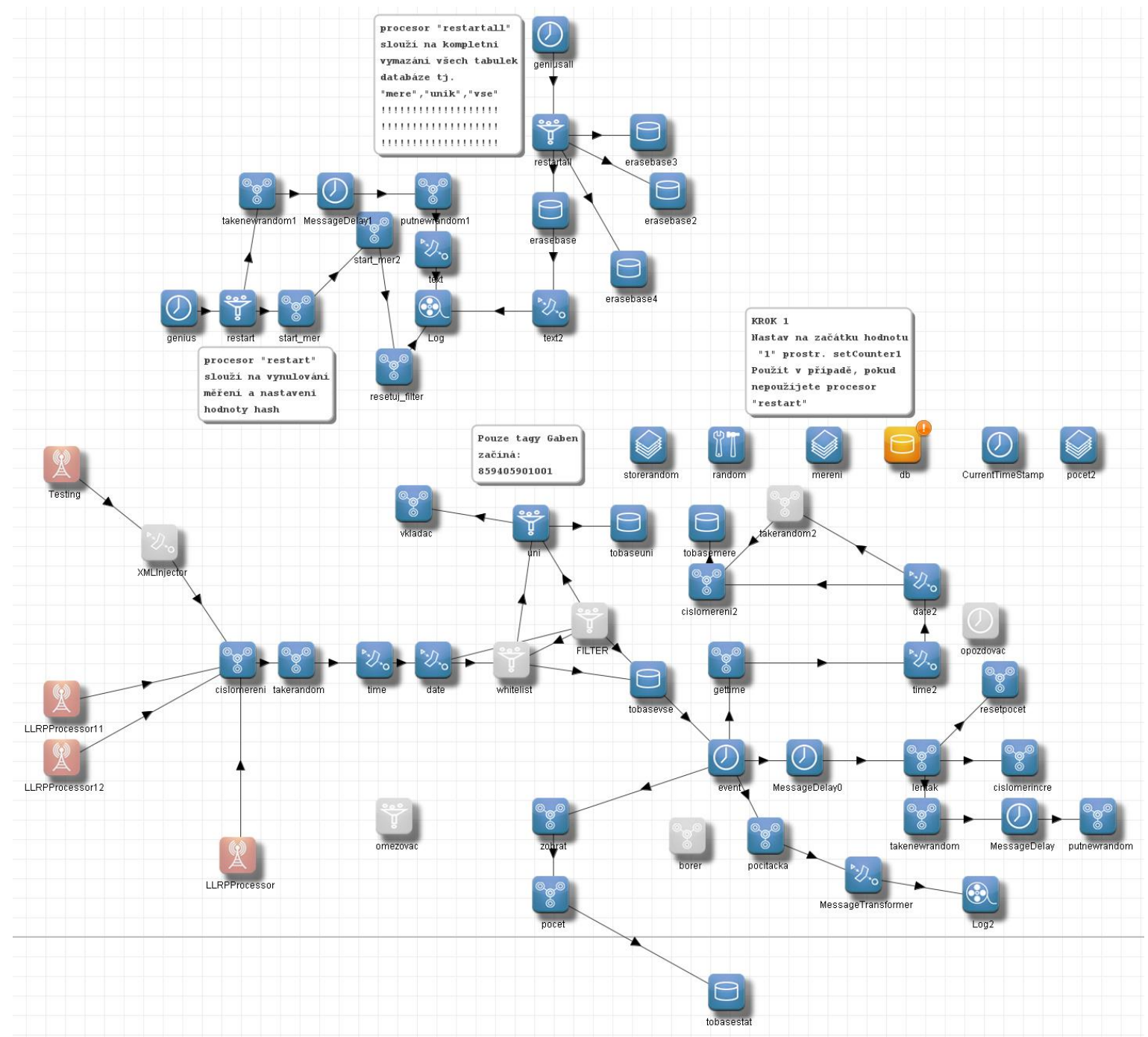

Obrázok 7. AMP konfigurácia

Po nakonfigurovaní jednotlivých komponentov RFID systému sme zostavili konštrukciu, na ktorú sme umiestnili ako čítacie zariadenia, tak aj príslušné antény. Pri prechodoch paliet boli zapojené jednak bočné, ako aj vrchné antény.

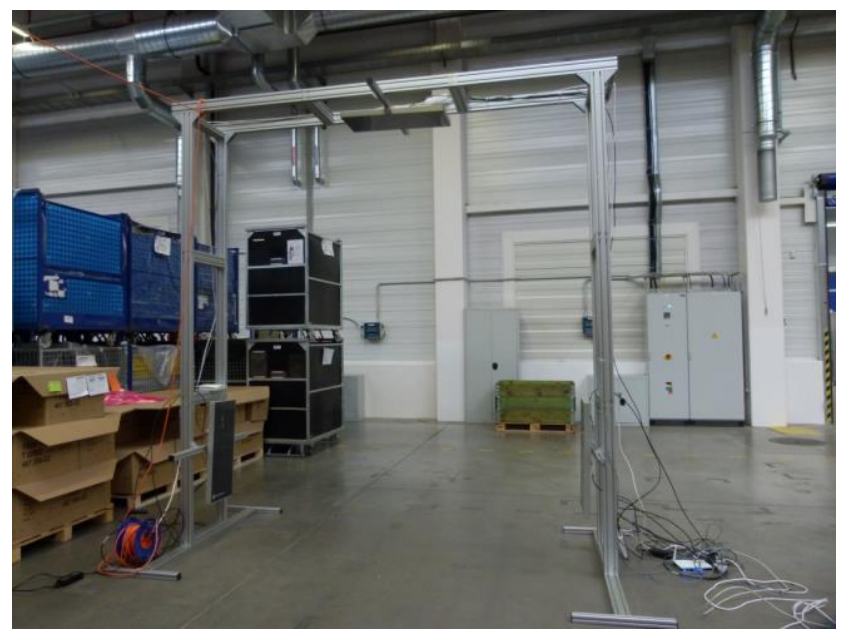

Obrázok 8. RFID brána- konštrukcia 


\section{Výsledky testovania}

Čo sa týka výsledkov testovania môžeme skonštatovat', že dopadli nad mieru úspešne ked'že sme v požadovanom rozložení svetlometov dosiahli 100\% čitatel'nost'.

Celý proces bol rozdelený na niekol'ko fáz, resp. typov testov:

1. Skúšobný test (meranie 1)- v rámci tohto testu bolo potrebné správne nakonfigurovat' našu aplikáciu a vyladit' rozmiestnenie antén čítacieho zariadenia ako aj nastavit' potrebnú intenzitu signálu, ktorý vyžarovali príslušné antény. Vzhl'adom na fakt, že sa v prostredí nachádzalo viacero tagov mimo umiestnenia na svetlometoch, museli sme vel'mi dôsledne vykonat' príslušné pred-testy. Stalo sa totižto, že bolo načítaných aj viac tagov ako bolo očakávaných a naopak, pokial' boli tagy stále v dosahu elektromagnetických vín, aplikácia vyhodnotila chybne príslušné načítané údaje. Tieto konfiguračné zmeny bolo nutné vykonat' samozrejme aj v závislosti od prevádzkového prostredia, v ktorom sa merania uskutočnili.

2. Reálny test - realizovaný bez zásahov do aplikácie, ktorý bol dekomponovaný do dvoch meraní:

a. Merania troch paliet za sebou, ktoré boli t’ahané dopravným vozíkom (t’ahačom) merania 2,3 .

b. Meranie samostatnej palety, ktorá bola tlačená ručným hydraulickým vozíkom (palet'ákom) - merania 4,5

V nasledujúcej tabul'ke a grafe sú prehl'adne spracované výsledky meraní, ktoré boli vyššie popísané.

\begin{tabular}{|l|c|c|c|c|c|c|}
\hline \multicolumn{1}{|c|}{ Oranačenie } & $\begin{array}{c}\text { Načitané } \\
\text { tagy }\end{array}$ & $\%$ úšpešnost & $\begin{array}{c}\text { Očakávané } \\
\text { tagy }\end{array}$ & \multicolumn{3}{|c|}{ Tabulka 1. Výsledky merani } \\
\hline Meranie 1 & 35 & $97 \%$ & 36 & Skúšobný test & 3 palety & $\begin{array}{c}\text { Kalibrácia a } \\
\text { nastavenie } \\
\text { aplikácie }\end{array}$ \\
\hline Meranie 2 & 39 & $100 \%$ & 39 & do skladu & 3 patety & test \\
\hline Meranie 3 & 39 & $100 \%$ & 39 & do skladu & 3 palety & test \\
\hline Meranie 4 & 13 & $100 \%$ & 13 & Test & 1 paleta & test \\
\hline Meranie 5 & 13 & $100 \%$ & 13 & Test & 1 paleta & test \\
\hline
\end{tabular}

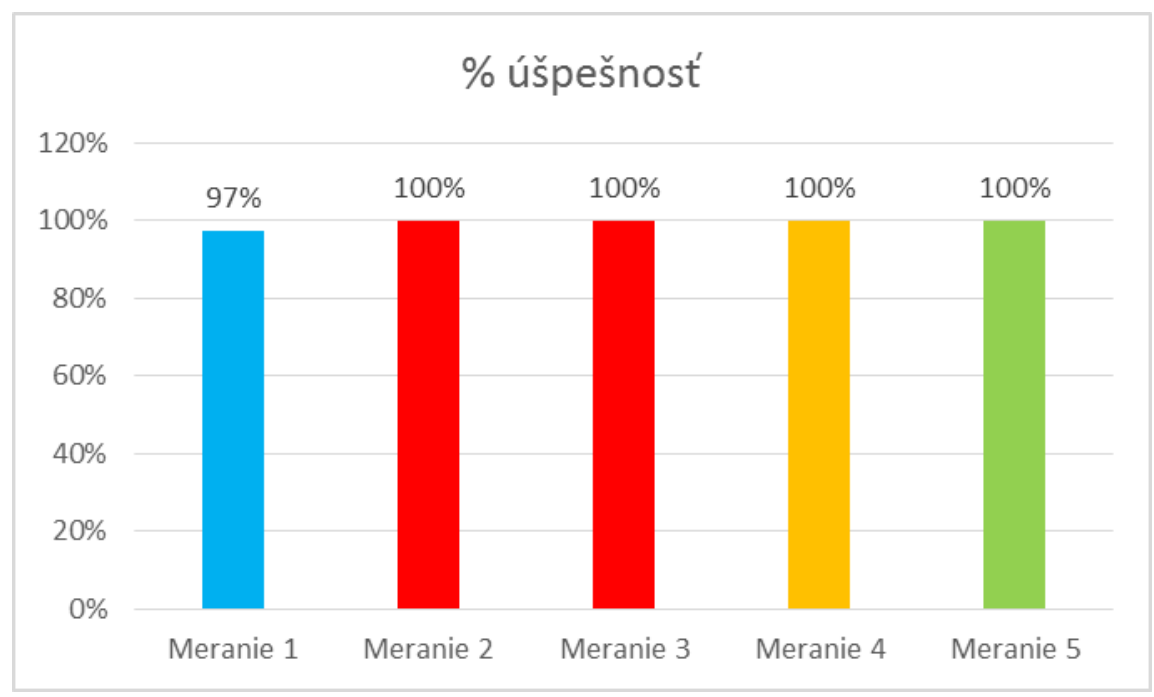

Obrázok 9. Výsledky meraní 
Pri meraniach 2 a 3 sme testovali reálny prechod troch paliet naplnených prednými svetlometmi KIA Sportage. Ako je možné z grafu vyčítat', dosiahli sme 100\% čitatel'nost', čo dáva predpoklad k použitiu RFID technológie pre tieto účely. Následne sme testovali aj prechody jednotlivých paliet kde sa čitatel'nost' žiadnym spôsobom nemenila.

\section{Záver}

Pri pohl'ade na výsledky testov a spokojnost'ou zodpovedných pracovníkov nemenovaného podniku s realizovanými meraniami môžeme skonštatovat', že ciel', s ktorým sme išli na testovanie, sa nám podarilo naplnit'. Dosiahla sa 100 \% čitatel'nost' RFDI tagov umiestnených na svetlometoch KIA Sportage, čo nám dáva vhodný základ pre aplikáciu tejto technológie v rámci identifikácie autodielcov v automobilovom priemysle. Týmto je možné vyvrátit' dohady o aplikovatel'nosti technológie RFID v logistike resp. v automotive. Stretávame sa však stále s názormi vo väčšine prípadoch nefundovaných odborníkov, ktorí nikdy testy nezrealizovali, že táto technológia je nerentabilná a zastaralá. Opak je však pravdou, čoho dôkazom je aj celosvetový nárast trhu a predaných komponentov RFID technológie.

\section{Literatúra}

[1] MAŠEK, J., ČAMAJ, J., ČERNÁ L.: Possibilities of application the methods of network analysis to optimize warehouse logistics = Možnosti aplikácie metód siet'ovej analýzy pri optimalizácii skladovej logistiky, In: LOGI 2012 : 13th international scientific conference, November 22th, 2012 in Pardubice, Czech Republic : conference proceedings. - Brno: Tribun EU, 2012. - ISBN 978-80-263-0336-7. - S. 257-263.

[2] TENGLER, J., VACULÍK, J.: Notifikace doručení poštovních zásilek prostřednictvím mobilního telefonu $=$ Notification of delivery postal mail trough mobile phone / In: POSTPOINT 2013 [elektronický zdroj] : „Delivering innovation and training in postal technology and services" : [10.] medzinárodná konferencia zástupcov poštových správ a univerzít : Rajecké Teplice, Slovakia, 19.-20. september 2013 : zborník príspevkov. Žilina: Žilinská univerzita, 2013. - ISBN 978-80-554-0747-0. s. 189-196.

[3] MICHÁLEK, I., VACULÍK, J.: RFID Planning levels for postal and courier services. In: Future Role of Postal Services in the Face of New Market Conditions and Communication Technologies, Pardubice, Czech republic, December, 2008 (pp. 144151). Pardubice: University of Pardubice.

[4] FINKENZELLER, K.: RFID Handbook: Fundamentals and Applications in Contactless Smart Cards, Radio Frequency Identification and Near-Field Communication. UK: John Wiley \& Sons, Ltd.., 2010. 40 s. ISBN 978- 0470695067

\section{Grantová podpora}

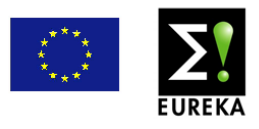

E!7592 AUTOEPCIS - RFID Technology in Logistic Networks of Automotive Industry (RFID technológie v logistických siet'ach automobilového priemyslu) Za podpory Ministerstva školstva, vedy, výskumu a športu.

- 4/KS/2014 - Výskum faktoru ovlivňujícich obsah prepravovaných balikových zásilek prostřednictvím senzoru pohybu, teploty, otřesu a dalšich. 